\title{
First Record of Mealybug (Paraputo odontomachi Takahashi) and Two Ambrosia Beetles (Amasa sp. and Crossotarsus sp.) on Clove in North Sulawesi
}

\author{
Jackson F. Watung ${ }^{1,2^{*}}$, Max Tulung ${ }^{1,2}$, Christina L. Salaki ${ }^{1,2}$ \\ ${ }^{1}$ Department of Plant Pests and Diseases, Faculty of Agriculture, Sam Ratulangi University, Manado, North Sulawesi \\ 95115, Indonesia \\ ${ }^{2}$ Entomology Study Program, Postgraduate, Sam Ratulangi University, North Sulawesi, Manado 95115, Indonesia \\ *Corresponding author. Email: jacksonwatung@unsrat.ac.id
}

\begin{abstract}
A mealybug Paraputo odontomachi (Hemiptera: Pseudococcidae) and two species of ambrosia beetles, Amasa sp. (Coleoptera: Curculionidae: Scolytinae) and Crossotarsus sp. (Coleoptera: Curculionidae: Platypodinae) on clove trees were recorded for the first time in Minahasa, South Minahasa and South Bolaang Mongondow District, North Sulawesi Province. These polyphagous insects are known to live on several host plant species. The objective of this research is to identify the mealybugs species, and then beetles on clove to determine the type incidence and the effect of the pest attack on clove. Field observations showed that the three insects were found on clove trees in Minahasa. For the first time the assessment of pest infestation and percentage incidence (PI) were carried out in the clove plantations area of PT Kawanua Kahuripan Pantera in Lungkap and Kombot Villages, South Bolaang Mongondow District. P.odontomachi generally live around the base of roots and stems. The association between P. odontomachi with black ant (Dolichoderus thoracicus) broaden its distribution to the middle part of the tree. Ambrosia beetles, Amasa sp. damage the plants by bore holes on the stems and branches while Crossotarsus sp. only bore on the stems. Attacks by ambrosia beetles usually result in the death of stem and branch tissues; plants may exhibit dieback following the attacks. However, mass attacks of these beetles can lead to plant death.
\end{abstract}

Keywords: Amasa, Crossotarsus, borer, Paraputo odontomachi, mealybug

\section{INTRODUCTION}

Land conversion from natural forest ecosystems and other estate crop areas into clove plantations is increasing in several districts in North Sulawesi Province. Directorate General of Estate Crops reported that in 2017, the clove plantations area in North Sulawesi amounted to 74, 793 ha and the North Sulawesi Plantation Service in its $20174^{\text {th }}$ Quarter Report stated that clove cultivation area increased to 75,297 ha. North Sulawesi has the largest clove plantation area in Sulawesi, and even in Indonesia. However, its productivity is lower than the other two clove producing provinces, South Sulawesi and Southeast Sulawesi [1]. Climatic conditions, management practices, plant age, pests, and diseases are factors that affect clove productivity [2].

Habitat loss due to land conversion into monocultures can directly influence the life of faunas, such as insects. They inhabit the area where the number of host plants that play roles as shelters and food sources is decreasing. At the same time, the monoculture cultivation plants are present in large numbers in their habitat. Thus, triggers insect exploration and adaptation to new niches and food sources [3].

Several years ago, North Sulawesi Plantation Service received a report from farmers regarding mealybugs attacked on the root and the trunk base of clove trees. At the end of 2014, an integrated survey held by the Faculty of Agriculture, Sam Ratulangi University and the North Sulawesi Plantation Service confirmed the presence of mealybugs in several clove plantations in Minahasa and South Minahasa Districts. Based on the results from the first assessment, in 2016 to early 2017, both institutions did another extensive field survey in several clove plantations in South Bolaang Mongondow District. The surveys showed that high population mealybugs were present at the PT. Kawanua Kahuripan Pantera (KKP). Other than mealybugs, the results also showed that two ambrosia beetles that were damaging the stems, branches and twigs of clove plants. Based on the field survey data, it is necessary to conduct preliminary studies of these pests to determine the type, incidence, and the effect of the pest attacks on cloves. The objective of this research are to identify the mealybugs species, and then beetles on clove to determine the type incidence and the effect of the pest attack on clove. 


\subsection{Paper Structure}

These studies were carried out in two locations. The first study on the infestation of mealybug and ambrosia beetles were investigated in the central areas of clove plantations in Minahasa and South Minahasa Districts from January to March 2017. Meanwhile, the second study on the pest incidence and symptoms of the damaged plants were examined in three sample plots at Lumbuguwon, Tapamayondi, and Tamanok resorts inside PT. Kawanua Kahuripan Pantera (KKP) area which located in Kombot Village and Lungkap Village, Pinolosian Subdistrict from April to July 2017. Random observations carried out by diagonal transect on $100 \mathrm{~m} \times 300 \mathrm{~m}$ plot. We investigated 100 trees in each plot. The percentage of incidence was calculated using the formula: $\mathrm{P}=\mathrm{n} / \mathrm{N}$ x $100 \%$, in this case, $\mathrm{P}=$ percentage of attacks; $\mathrm{n}=$ number of trees attacked; $\mathrm{N}$ $=$ total number of trees observed.

The beetles specimens determined based on the morphological characters using Lucid key [4]. The identification was conducted at the Entomology and Plant Pest Laboratory, Plant Pests and Diseases Department, Faculty of Agriculture, Sam Ratulangi University. Mealybug specimens were at the Laboratory of Plant Pest Diagnostic Center, California Department of Food and Agriculture (CDFA) Sacramento, California.

\subsection{Our Contribution}

This paper presents some information about three new insect pests on clove in North Sulawesi Province, and the pest status of each of them based on the incidence of attacks and the effect on clove. This information is a basic knowledge to concept the control management

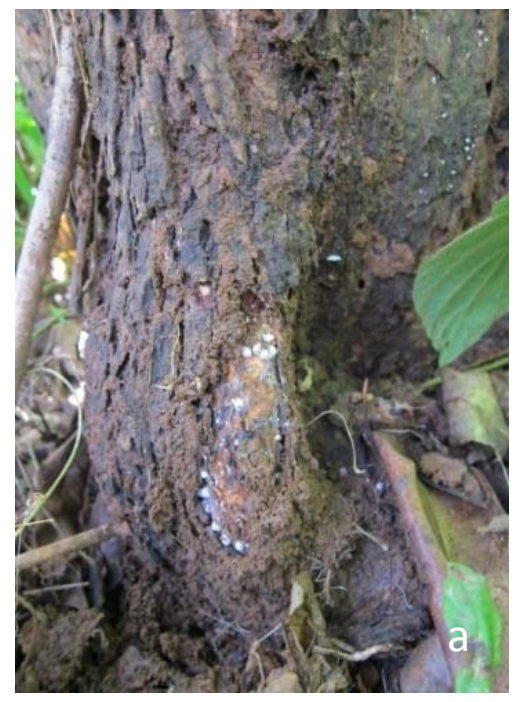

\subsection{Morphology and the Damaged Symptoms on Host Plants}

Paraputo odontomachi. Morphologically has wide and almost round in shape, with convex dorsal, covered with white mealy wax and wax filaments on the body edges (Figure 1). Body length $1.90-2.75 \mathrm{~mm}$ and width 1.40 $2.20 \mathrm{~mm}$. The antenna consists of 7 segments, sometimes 8 segments. Legs well developed with large and curved claw.

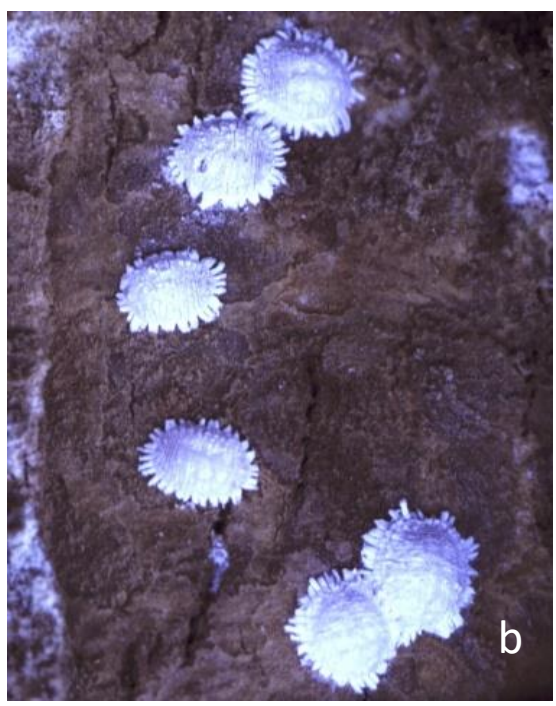

Figure 1 Paraputo odontomachi mealybug: (a) P. odontomachi attack at the base of the clove tree trunk, (b) $P$. odontomachi (2.5x magnification) 
Paraputo odontomachi has large and protrudingostiole with sclerotized inner edges and filled with small and trilocular pores. There are 17 recognizable pairs of cerarii; 2 sturdy cone-shaped setae in each anal lobe cerarii [5].

Mealybug $P$. odontomachi is a polyphagous insect, with host distributed in several families such as Crypteroniaceae, Elaeocarpaceae, Euphorbiaceae, Rubiaceae, and the mealybug also known as a pest on Mangosteen (Clusiaceae) in Indonesia and Southeast Asia [5, 6]. The discovery of $P$. odontomachi as a pest on the clove tree is the first record of the pest attacks family Myrtaceae.

The nymphs and females $P$. odontomachi usually live in a group at the roots and trunk base of clove trees around the soil surface, but sometimes they can be found in tree branches. The mealybug dispersal to the higher part of the trees is assisted by black ants, Dolichoderus thoracicus (Hymenoptera: Formicidae: Dolichoderinae). A similar association between $P$. odontomachi with ants on different parts of Elaeocarpus sp. The mealybugs were associated with Odontomachus sp. (Hymenoptera: Formicidae: Ponerinae) on the roots of Elaeocarpus sp., while on the trunk, $P$. odontomachi assisted by Dolichoderus sp. [5].

There may be a correlation between the presence of $P$. odontomachi and with the spread of root and stem rot diseases on clove trees. The mealybugs are often found under the root gaps and stem barks of infected trees. A severe attack of the disease can cause a decline in plant conditions and eventually die. Dead trees become easily fallen by the strong winds due to the decaying root. The symptoms are similar to black root rot in cloves caused by Dematophora sp., an asexual form (anamorph) of Roselina pepo. The fungal-infected plants showed symptoms of decaying root, followed by yellowing leaves and, eventually, the plant death [7]. Another example of the mealybug-fungi association has been reported on coffee in Kenya. Association between African coffee root mealybug, Planococcus fungicola and Diacanthodes novoguineensis an anamorph of Bornetina sp. which results in symptoms such as leaves turn yellow and fall, sometimes causing plant death, which similar to the symptoms of the mealybug-fungi association on cloves [8].

Amasa sp. Sexually dimorphic in body size where fieldcollected females Amasa sp. were larger ( 4 mm long) than males $(\sim 2 \mathrm{~mm})$ collected from the same locations as illustrated in Figure 2a. The head and legs are blackishbrown while thorax, pronotum, abdomen, and elytra are black. The antenna is black, four segments with a clubshaped fourth segment, which is not segmented and pubescent. The posterior elytra have sharp angular shapes so that the tip of the abdomen appears to be cut off. Posteriorly, female weevils have two small spikes on elytra. Coxa on the first and second legs looks like connected [9]. The genus of Amasa is known to have many host plants, but the primary host plant is family Myrtaceae [10]. Amasa sp. is called a key-hole borer due to the key or letter L shaped gallery, which is a horizontal hole on the stem and shifts sideways toward the end of the gallery. The beetle bore on twigs, branches, and tree trunks of young to old clove plants. The death tissue around the hole has blackish-brown bands. Necrotic tissue extends to the top and bottom of galleries. The symptoms appear as a result of fungal pathogen infection.

Ambrosia beetles are widely associated with ambrosia fungi, including fungi that have implications as plant pathogens, such as the spread of Ceratocystis fimbriata released through beetle frass as an aleuroconidia lead to Ceratocystis wilt disease on eucalyptus trees [11]. Amasa truncata transmits Ceratocystis sp. which causes leaf wilting and twigs dieback on the Eucalyptus globulus in New Zealand [10]. Fungal pathogenic infection of Ceratocystis polycroma causes blackish-brown necrotictissue on the clove stem, along with leaf fall disease are causes of decreasing clove populations in North Sulawesi[12].
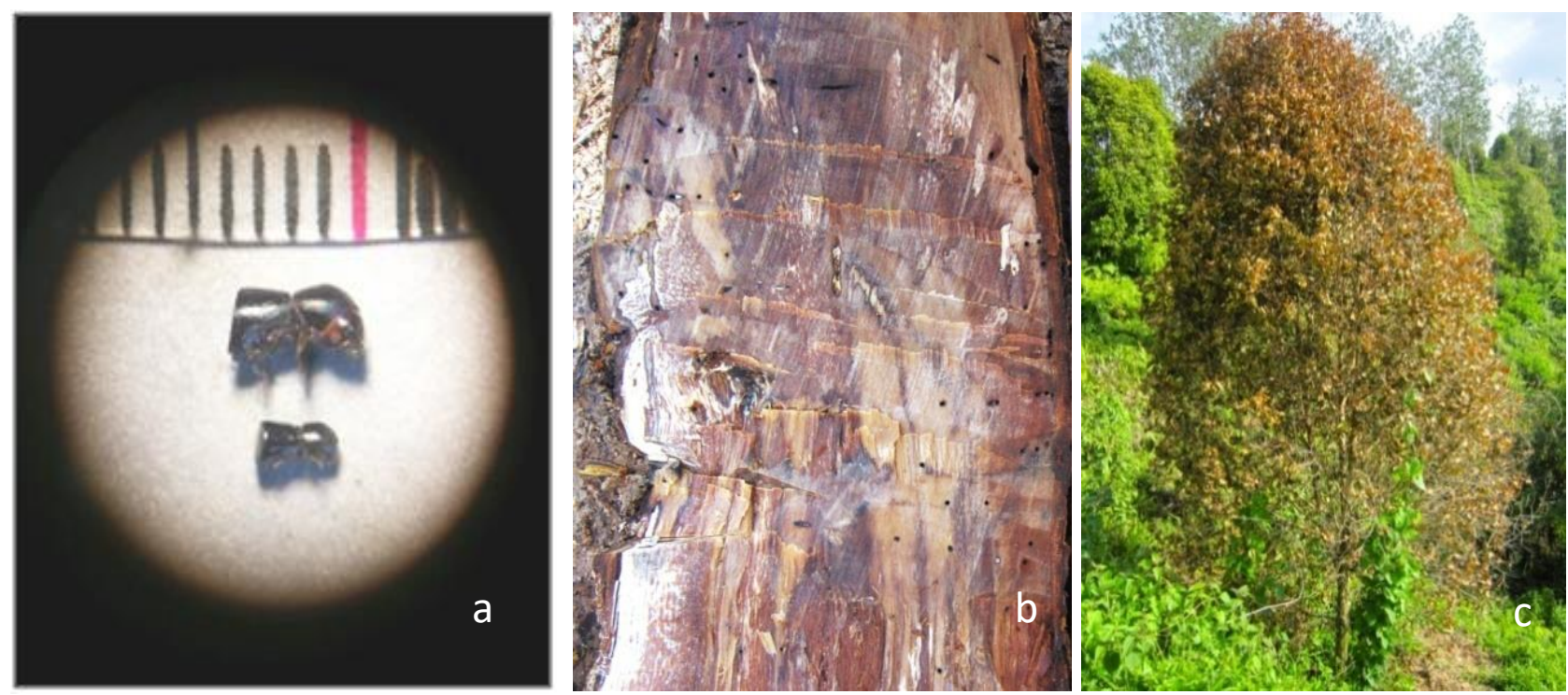

Figure 2 Key-hole borer beetles: (a) Amasa sp. female (upper) and male (under) (2.5x magnification), (b) the holes in the stem of Amasa sp, (c) clove trees that died due to attack by Amasa sp. 

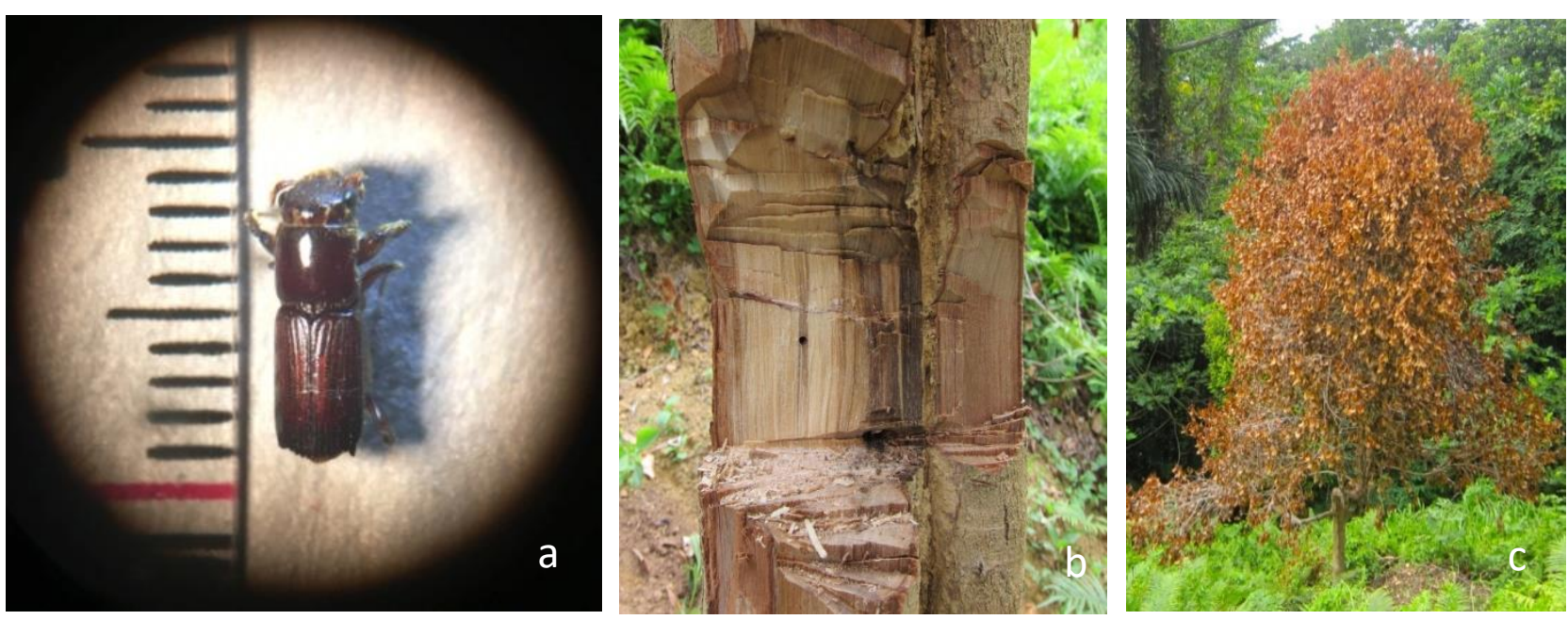

Figure 3 Pin-hole borer beetle. (a) Crossotarsus sp. (2.5x magnification), (b) symptom attack of Crossotarsus sp. on the stem, (c) clove tree that died due to the attack of Crossotarsus sp.

Crossotarsus sp. The body size about $8 \mathrm{~mm}$ long, with the head and pronotum are dark-brown, elytra reddishbrown with dark brown apex (Figure 3). Head with yellowish-white hair-like setae. Four-segmented antenna with large asymmetrical scape; large club-shaped fourth segment which is not segmented. The short antenna consists of four segments, large asymmetrical scape, the last segment is in the shape of a large club and is not segmented. There are parallel grooves and small punctures on the surface of the elytra. The apex front leg tibia is hooked with a thorn-like shape. Crossotarsus sp. has angular-shaped femoral grooves in the anterior pronotum and rounded posteriorly, a row of small, spike-like protrusions at the tip of the elytra; the male venter of the sub-vertical abdomen assembly with elytra; the male metepisternum has a round nodule at the posterior edge. The outer part of protibiae and mesotibiae with transverse grooves [13-15].

Crossotarsus sp. is known as pin-hole borer due to the horizontal hole on the tree trunk. This polyphagous beetle usually attacks living trees and logs. In the South Pacific Islands, Fiji and Samoa islands, C. externedentatus cause problems on Eucalyptus ciriodora, E. grandis, Psidium guayava, Syzygium corynocarpum (Myrtaceae), Leucaena sp. (Fabaceae), Theobroma cacao (Sterculiaceae), Ficus sp. (Moraceae) [15, 16,]. In Malaysia, it was reported that $C$. comatus live on Afzelia bakeri, Parkia speciosa (Fabaceae), Koompassia excels (Caesalpiniaceae), Grewia sp., Sterculia macrophylla (Malvaceae) [17].

Necrotic symptoms around the gallery of Crossotarsus sp. shaped blackish-brown striationis the same as the symptom attack of Amasa sp. It proves that both ambrosia beetles can transmit pathogenic fungi to the clove tree that they attack.

\subsection{Incidence of Pest Attack}

The incidence of mealybug and ambrosia beetles on the clove trees at PT. KKP plantation area showed differences in its predominance, the average percentage incidence of $P$. odontomachi and ambrosia beetles Amasa sp. and Crossotarsus sp. were $40.7 \%, 3 \%$, and $2 \%$, respectively. The highest percentage of $P$. odontomachi attack occurred at Tamonok and Tapamayondi resorts, which were $44 \%$ and $43 \%$, respectively, followed by Lombuguwon $35 \%$. Slight differences in the percentage of incidence may be related to plant conditions, management practices, and plantation environment. The site of the Lombuguwon resort is located on the upper hills overlooking the coast of Kombot Village. The influence of wind and warm night air from the sea can reach most areas of the resort. Clove trees generally appear to grow well when some branches in the lower part are trimmed so that they do not cover soil surface, thereby reducing the humidity around the base of the tree trunk. The Tamonok and Tapamayondi resort are located in valley and hill areas close to the buffer zone of Bogani-NaniWartabone National Park. The plant conditions in Tamonok and Tapamayondi resorts are not healthy as those in the Lombuguwon resort, even in certain places have thin layer of soil and rocky which lead to stunted trees. The percentage incidence from Amasa sp. and Crossotarsus sp. still very low. Based on pests incidence data, the status of $P$. odontomachi can be categorized asa major pest, while both of ambrosia beetles Amasa sp.and Crossotarsus sp. are minor pests or potential pests.

\section{CONCLUSION}

It is the first record of all three insect pests, Paraputo odontomachi, Amasa sp. and Crossotarsus sp., which were found to live on clove trees as its host plant. The mealybug $P$. odontomachi status can be categorized as a major pest, while Amasa sp. and Crossotarsus sp. as a minor pest. However, these pests attacks can be more harmful since they have potential as vectors of fungal plant pathogens. 
[8] G.W. Watson, J.M. Cox, Identity of the African coffee root mealybugs, with descriptions of two new species of Planococcus (Homoptera: Pseudococcidae), Bull. Entomol. Res. 80 (1) (1990) 99-105. DOI: https://doi.org/10.1017/ S0007485300045971

[9] H.L. Rainho, W.D. Silva, M.O.G. Leite, J.M.S. Bento, Notes on the distribution of the exotic ambrosia beetle Amasa truncata (Erichson) (Coleoptera: Curculionidae: Scolytinae) in Southeastern Brazil, Coleopts. Bull. 72 (4) (2018) 1-3. DOI: https://doi.org/10.1649/0010-065X72.4 .870

[1] Anonymous, Tree crop estate statistics of Indonesia 2015 - 2017 clove, Secretariate of directorate general of estate crops, Directorate general of estate crops, Ministry of agriculture, 2016

[2] A. Ruhnayat, D. Wahyuno, D. Manohara, R. Rosman, Clove cultivation, in: F. Karwur,H. Semangun (Eds), Clove history, Cultivation and Industry, Indesso and Master of Biology Christian University Satya Wacana, P.T. Gramedia, 2014, pp. $45-72$

[3] J.F. Watung, Insect pests on agroforestry system of clove and waru gunung plants and control study of termite using local isolate of entomopathogen fungi Metarhizium anisopliae, Ph.D. Thesis, Postgraduate, Sam Ratulangi University, Manado, 2018

[4] S.M. Smith, R.A. Beaver, A.I. Cognato, J. Hulcr, A.J. Redford, Southeast Asian ambrosia beetle id, Lucid key for Southeast Asian xyleborine species, $2017 . \quad$ http://idtools.org/id/wbb/seaambrosia/key.php

[5] D.J. Williams, Mealybugs of Southern Asia, The Natural History Museum, London, 2004

[6] S.P. Chen, W.J. Wu, J.Y. Wong, Mealybugs (Hemiptera: Coccoidea: Pseudococcidae) intercepted from imported plant agricultural products in Taiwan, Plant Protect. Bull. 55 (3) (2013) 79-104

[7] M.L. Oliveira, G.L. Melo, A.R.R. Niella, V.R. Silva, Black rot root caused by Roselina pepo, a new disease of the clove tree in Brasil, Trop. Plant Pathol. 33 (2) (2008) 90-95. DOI: https://doi.org/10.1590/S1982-5676200800020000 2

[10] C.A. Flenchtmann, A.I. Cognato, First report of Amasa truncata (Erichson) (Coleoptera: Curculionidae: Scolytinae) in Brazil, Coleopts. Bull. 65 (4) (2011) 417-421. DOI: https://doi.org/10.1649/072.065.0419

[11] TC. Harrington. The genus Ceratocystis: where does the oak wilt fungus fit? in: R.F. Billings, D.N. Appel (Eds), The Proceedings of the $2^{\text {nd }}$ National Oak Wilt Symposium, International Society of Arboriculture - Texas Chapter, 2008, pp. 27-41

[12] BH Assa, Study of clove leaf fall disease and its relation to insects, Ph.D. Thesis, Postgraduate, Sam Ratulangi University, Manado, 2014

[13] A. Nobuchi, TARC Report: The Platypodidae (Coleoptera) of Philippines, JARQ 18 (4) (1985) 327-330.

[14] S.L. Wood, Revision of the genera of Platypodidae (Coleoptera), Great Basin Nat. 53 (3) (1995) 259281

[15] R.A. Beaver, Ambrosia beetles (Coleoptera: Platypodidae) of the South Pasific, Can. Entomol. 132 (2000) 755-763. DOI: https://doi.org/10. 4039/Ent1327 55-6

[16] R.A. Beaver, The Biology of Samoan bark and ambrosia beetles (Coleoptera, Scolytidae and Platypodidae), Bull. Ent. Res. 65 (1976) 531-548. DOI: https://doi.org/10.1017/S0007485300006210

[17] F.G. Browne, Biological notes on some Malayan ambrosia beetles, Malayan Forest (Repr), 1935, in: CFC. Beeson, The Ecology and Control of the Forest Insects of India and the Neighboring Countries, The Vasant Press, Dehra Dun, India, 1941 